\title{
Article \\ The Role of Multi-Actor Engagement for Women's Empowerment and Entrepreneurship in Kerala, India
}

\author{
Murale Venugopalan ${ }^{1, *(1)}$, Bettina Lynda Bastian ${ }^{2}\left(\mathbb{C}\right.$ and P. K. Viswanathan ${ }^{1}$ \\ 1 Department of Management, Amrita Vishwa Vidyapeetham, Kochi 682041, India; \\ pk_viswanathan@asb.kochi.amrita.edu \\ 2 USEK Business School, Holy Spirit University of Kaslik, 1200 Jounieh, Lebanon; \\ bettinalyndabastian@usek.edu.lb \\ * Correspondence: v_murale@asb.kochi.amrita.edu
}

Citation: Venugopalan, Murale, Bettina Lynda Bastian, and P. K. Viswanathan. 2021. The Role of Multi-Actor Engagement for Women's Empowerment and Entrepreneurship in Kerala, India. Administrative Sciences 11: 31.

https://doi.org/

10.3390/admsci11010031

Received: 16 February 2021

Accepted: 11 March 2021

Published: 17 March 2021

Publisher's Note: MDPI stays neutral with regard to jurisdictional claims in published maps and institutional affiliations.

Copyright: (c) 2021 by the authors. Licensee MDPI, Basel, Switzerland. This article is an open access article distributed under the terms and conditions of the Creative Commons Attribution (CC BY) license (https:// creativecommons.org/licenses/by/ $4.0 /)$

\begin{abstract}
Entrepreneurship has been increasingly promoted as a means to achieve women's empowerment in the pursuit of gender equal societies by international development organizations, NGO's as well as national and local governments across the world. Against this, the paper explores the role and influence of multi-actor engagement on successful empowerment of women based on a case study of Kudumbashree program in a regional context of Kerala, in South India. Our objective is to examine the women empowerment outcomes of the Kudumbashree initiatives, implemented within a multi-actor engagement framework supportive of women's empowerment through capacity building and social inclusion programs. The case study demonstrates 'how multiple-level engagements help enhance women's development and support broad sustainable social change, in view of their sensitivity to the embeddedness of women's agency under specific socio-political and cultural contexts'. We find that Kudumbashree programs, through its multi-actor engagement, strives for an equilibrium between social change through policy and regulatory change (top down) and social change via mobilizing the people (bottom-up). From a policy angle, the key learnings from the successful outcomes of Kudumbashree may be considered for designing rural and urban community development programs with a focus on the multidimensional empowerment as well as social and economic inclusion of women and other marginalized communities.
\end{abstract}

Keywords: gender; women's empowerment; multi-actor governance; power; rural areas; Kudumbashree; Kerala

\section{Introduction}

Entrepreneurship has been increasingly promoted as a means to achieve women's empowerment in the pursuit of gender equal societies by international development organizations, NGO's as well as national and local governments across the world alike (Bastian et al. 2019). Women's empowerment is considered the pivotal prerequisite for human and sustainable development aligned with the UN sustainability goals under the UN 2030 agenda. It is expected that entrepreneurial activities lead to a certain financial and economic autonomy, which will enable women to liberate themselves from gendered constraints that have hindered the development of their potential (Nawaz 2019; Bastian et al. 2019). However, Ojediran and Anderson (2020) reveal how gendered formal and informal institutions in the Global South continue subjugating women and maintain the second-class status for female entrepreneurs despite empowerment efforts by various national governmental and international development agencies. Among others, research blames entrepreneurship programs that, based on a flawed neo-liberal economic logic, which is firmly anchored in Western thinking and which is blind with regard to the needs of different cultural contexts (Ennis 2019; Escobar 1992). Moreover, scholars increasingly pay attention to intersectional influences, such as gender, patriarchy, migration and displacement on women entrepreneurs 
(Welter et al. 2019; Bastian 2017), and to the important role of formal and informal institutional contexts (Brush et al. 2009). Critical entrepreneurship scholars conclude that women entrepreneurship often perpetuates the prevailing gendered and oppressive systems whilst failing to achieve women's empowerment and to overcome societal and institutional sexism (Muntean and Ozkazanc-Pan 2016).

In this context, multi-actor engagement models can play a crucial role in achieving empowerment objectives. Such models pool ideas and input from diverse stakeholders in empowerment processes. They also include disempowered women who get involved in decision-making processes, by discussing challenges, tackling complex issues and contributing to the development of suitable policies (Warner 2005). One of the critical attributes of multi-actor engagement models are that they observe a democratic approach for reaching decisions (Kusters et al. 2018). This approach socially includes women from heterogeneous backgrounds and groups (Warner 2005). Our research aims at contributing to a greater understanding of how multi-actor engagement and multi-level ties influence empowerment outcomes because they promote information sharing and the generation of trust among various actors. To date, few studies address the impact of multi-actor engagement on empowerment outcomes of entrepreneurial programs. The present research examines how the convergence of ideas and decisions among local administrative bodies and local self-help groups (SHG) supported female empowerment of poor rural women from socially marginalized communities in Kerala, India. Our work elucidates the benefits and challenges associated with transformative spaces that comprise multiple actors across and within scales, such as members of the community-based neighborhood help groups, traditional leaders, key government departments and members of various voluntary organizations. Concretely, we are interested in (a) socio economic factors that facilitate the empowerment processes and (b) how the multi-actor engagement approach played a critical role in the transformational development regarding empowered individual women and communities.

For this, we apply the case study method and explore the Kudumbashree program for women, which has been considered as one of the most successful empowerment endeavor in Kerala, India. Kudumbashree is an initiative of the State of Kerala, and its name signifies "family prosperity". The program relies strongly on local (women and community) participation in planning and operating empowerment activities. Kudumbashree applies a capability approach to empowerment (Sen 1999), which relies strongly on women's active involvement into planning and development processes, as well as political decision making at the grass roots level. We explore the role and effectiveness of Kudumbashree programs on women empowerment highlighting the role of critical multi-level elements and players supportive of women's empowerment and their advancement in economy and society. The Kudumbashree case shows how multiple-level initiatives can enhance women's development and support broad sustainable social change because such initiatives are sensitive to the embeddedness of women's agency into specific socio-political and cultural contexts. Kudumbashree represents a participatory, local governance approach to development, which respects the politics of location (Rice and Hancock 2016) that does not follow universalized assumptions regarding women's experiences (Adjei 2015).

Our paper is structured as follows: We first present literature concerned with empowerment, entrepreneurship and the role of multi-actor engagement. In order to identify drivers of women empowerment, we introduce the context of Kerala. This is followed by our case study that describes and analyzes the Kudumbashree's women empowerment program. Based on this, we propose and discuss a multi-actor engagement model for women empowerment. We conclude the paper with key findings and observations on the replicability of the Kudumbashree's empowerment model, followed by some pointers to policy interventions and future research. 


\section{Empowerment, Entrepreneurship and Multi-Actor Engagement}

Women's empowerment has received a lot of attention in social sciences and economic research (Al-Dajani and Marlow 2013; Wood et al. 2021; Ojediran and Anderson 2020). It is considered paramount for achieving gender equality as an important antecedent for poverty alleviation and socio-economic development (UNDP 2018). These assumptions also reflect in international development programs, such as the UN Sustainable development agenda for 2030 that ascribes a central role to female empowerment with its sustainable development goal 5 to induce social change in communities and countries (e.g., SDG 5). International development relates empowerment to multiple domains, such as health, education, political participation and economics (UNDP 2018; Duflo 2012; Sen 1999; Alsop et al. 2005).

A diverse amount of literature has contributed to the establishment and definition of the empowerment concept. Despite various analytical approaches dependent on the research field, a core of defining elements can be identified: empowerment is considered a process (Kabeer 1999; Mosedale 2005) that applies to individuals who are disempowered (relative to others) due to their social discrimination and marginalization; the process also applies to societies/communities and their evolution from less social and gender equal to equal (Al-Dajani and Marlow 2013). In this sense, empowerment is never just about individual change, but it also entails social changes (notably, with regard to changes in power structures within a society and community) (Sen 1999; Calas et al. 2009). Literature agrees that empowerment cannot be imposed on individuals, but necessitates their agency and willingness to work for personal and social transformation (Mosedale 2005; Narayan-Parker 2005). Therefore, concerned women must be cognizant of their subordination and marginalization due to prevailing structures, norms and ideologies (Batliwala 1994). On the other hand, women who are only recipients of change would not be considered as 'empowered' (Narayan-Parker 2005; Malhotra et al. 2002).

The empowerment process aims at enhancing individual's capabilities to make personal decisions and to transform these into desired outcomes (Mosedale 2005). To Kabeer (2005), this refers to the ability to take strategic choices, which are critical for the empowered to live the life they want. The concept therefore cannot be reduced to economic strength and autonomy of women, but always entails a process of social change (Calas et al. 2009), which requires active agency by women, as well their willingness to participate in change in their communities (Mosedale 2005). The pivotal notion of female agency in the process necessitates a bottom-up approach toward capability development (Al-Dajani and Marlow 2013; Sen 1999) that is considerate of cultural and institutional contexts (Wood et al. 2021).

Empowerment approaches have been criticized for neglecting the actual distribution of power within societies, and the effect of power dynamics based on race, gender, class or other categories (Rowlands 1995). Pratto (2016) points out that programs and studies emphasize individual agency, but tend to overlook the limited agentic capacities of the powerless. Disempowered individuals are often trapped in institutional voids (Mair et al. 2012), which expresses in reduced access to potential markets (Anderson and Lent 2017), and lack of resources, such as institutional and social network support as well as lack of access to information and knowledge that would allow the disempowered to exercise their agency (Bastian and Zali 2016; Chesney and Chesler 1993). However, access to such resources depends largely on the institutional environment (e.g., cultural and regulatory), which is reflective of dominant power structures and which favor specific social groups (Anderson and Lent 2017; De La Chaux et al. 2018). Thus, the success of empowerment also relies on the social inclusion of the disempowered into concerned institutions and their participation in the decision-making processes (Narayan-Parker 2005). Involving women in participatory organizational structures helps with breaking their social isolation and allows them to connect and interact with important stakeholders outside of their traditional family environment (Datta and Gailey 2012). Such social inclusion of the disempowered is mirrored in grass root and participatory community approaches that rely on multiple level actors and on strong representation of disempowered individuals and communities in deci- 
sion making bodies during the empowerment process (Janssens and Brett 2006). In this context, Gaventa (2006) shows how the successful implementation of empowerment programs depends on societal diversity that considers the interdependencies of multiple related stakeholders. Empowerment is possible when it involves different actor categories, such as formal/informal, public/private and profit/non-profit (Avelino and Wittmayer 2016) and if it is socially inclusive to disempowered people who are enabled to influence the behavior of relevant institutions and their objectives (Narayan-Parker 2005). Such social inclusion hinges on decentralized decision-making, which stimulates self-governance and mutual interactions between different stakeholders (Hooghe et al. 2020; Tasan-Kok and Vranken 2008). Horizontal and vertical collaboration and coordination promote participation and bottom-up approaches to decision-making and strategy development (Knüppe and Pahl-Wostl 2013). Multi-actor approaches, which include women's voices (Rowlands 1995, 2016) and which involve the interests of multiple actors and their relationships with each other (Avelino and Wittmayer 2016; Gaventa 2006), allow to effectively address highly complex societal issues (Vangen et al. 2015). Approaches that support engagement of multiple stakeholder benefit from diverse types of leadership practices that provide "fresh" perspectives that support innovative solutions (Craps et al. 2019). Schön and Argyris (1996) propounded the view that learning within the organization is the outcome of very laborious interactive events in which actors openly engage in high quality communication, which results in pragmatic, innovative solutions. In a similar manner, in a multi-actor engagement approach, diverse stakeholders constructively exchange their different viewpoints, in order to generate mutually acceptable solutions and positions (Craps et al. 2019). Via this process, they undergo an extended learning course which enables them to identify the real-world issues and devise mechanisms to bring in changes.

In the following, we introduce the case of Kudumbashree, Kerala, which shows the effectiveness of multi-actor approaches for the promotion of women's empowerment.

\section{Context: Kerala}

Kerala is a state in southwest India with a population of approximately 33.4 million people (Census 2011), which is hardly 3\% of the national population. The state has received international acclaim for its unique Kerala model of development and the commendable progress in human development, poverty reduction and achievements in social as well as health sectors, despite lower levels of economic growth and per capita income (Dreze and Sen 1995, 2013; Véron 2001). Kerala is rated continuously high with higher literacy rates, women's empowerment, maternal health and lower infant mortality compared to many other Indian states (Parwez 2016). The Census of India data show that women in Kerala have an excellent demographic status, with the highest sex ratio of 1084 (females per 1000 males) in India, against the national average of 943, and above other states, such as Tamil Nadu (996), Maharashtra (929), Gujarat (919) and Haryana (879). Notably, children aged 0-14 years formed $23.44 \%$ of the total population in Kerala, $49 \%$ of whom were girls. Furthermore, about $22 \%$ of all households in Kerala were female-headed as against the national average of $11 \%$ (GOK 2021). The national family health survey (NFHS) 2005-06 revealed that Kerala reported a positive correlation between education and married women's participation in decision-making on family matters with almost $63 \%$ participating in decision-making as against Gujarat (56.7\%) [NFHS, 2008]. Dreze and Sen $(1995,2013)$ observed that, despite low economic growth, the state's emphasis on education and health care ensured greater public participation and public action, as compared to other states. However, despite women having a higher degree of access to education and enjoying superior health facilities, the same was not witnessed in their social positioning or public participation levels, including participation in economic sectors, political and governance spheres.

As widely held, historically, women in Kerala had experienced deprivation with respect to enjoying social status equal to men, which got accentuated with women not having rightful access to economic and productive resources, such as land, institutional credit, etc. 
However, apparently, women had ownership rights over land and other properties as permitted under the matrilineal social system; in actuality, they could not exercise the right due to the strong patrilineal and patriarchal systems prevailed in the state until recent decades (Devika and Thampi 2007). Furthermore, women from landowning households were constrained by access to land, as the progressive land reform measures had imposed ceiling and land redistributive measures, mostly affecting the medium and large farm households in Kerala. While women did not benefit from non-farm employment opportunities due to the social stigma attached to women entering the labour markets, the women from the socially and marginally deprived communities (say, scheduled castes and scheduled tribes) worked as farm labourers as well as low-paid menial and domestic workers with low wages and poor working conditions in agriculture (Saradamoni 1999; Franke 1993) and the plantation sectors (Viswanathan and Shah 2016). The prevalence of gender wage differences is yet another indicator of gender inequality in the state that manifested the lower participation of women in the labour market (Kannan 1999). The gender disparity in wage rates is obvious both in informal or unorganised sectors as well as regular/salaried employment (GOK 2021). It was in this historic context that the launching of Kudumbashree initiative came as a game changer in Kerala, giving a unique opportunity for women to forge ahead through mobilisation and collective action and thereby overcoming the continued deprivations and becoming instruments of economic development and social transformation in the state.

Kerala's distinct case has been highlighted by many academic and non-academic writers (Sen 1999) as a state known for poverty eradication measures. This feat was achieved mainly due to the proactive role of the state in implementing land reforms and providing free and easy access to education and health services. The decentralized planning that Kerala had launched at the initiatives of the Left Democratic Front (LDF) during the period (1996-2001) unleashed the Peoples' plan campaign/movement. The state had transferred 35-40 percent of the state's annual spending to the local (governance) bodies (Kadiyala 2004). This amount increased to a budget of rupees Rs 1 billion/year (approximately 25,00,000 USD based on US -India currency average exchange rate during the period) apart from centrally supported schemes and institutional loans that local bodies could get with Government guarantees. Several functions associated with basic needs, employment and revenue spawning activities in farming and other related sectors were also included with peoples' participation, especially, women as the core of those activities. Funds were allocated for supporting various local development projects, where women also were considered major benefactors (Isaac 2001). The people's plan campaign, which was augmented with a mass campaign similar to Kerala's literacy campaign in the 1980s, had helped strengthen and empower the local government bodies to draw plans by involving people, especially, women from neighborhood groups. From the above, it may be concluded that the success of the peoples' planning movement had given a fillip to the rural youth, especially women, to constantly engage in the local development process, which has further been facilitated by availability and access to financial resources to spend on economic and social welfare projects in the local areas, imparting the required capabilities and skills in the successful implementation of the projects.

\section{Drivers of the Need for Women's Empowerment}

Here, we examine some of the important factors that acted as the driving forces for empowerment of women in Kerala. The state having a high standard of living is also complemented with a well-laid out public distribution system, coinciding with higher minimum wages across job categories compared to rest of Indian states. Nevertheless, gender wage differences are reported both in farming and off-farm activities within the state. Women also faced problems of higher levels of unemployment, including educated unemployment. It is reported that the unemployment rate was much higher among females (17.1\%) as compared to males (5\%) at the state level. While the rural unemployment rate was $4.7 \%$ among males, it was the highest at $15.6 \%$ among females; and the urban unem- 
ployment rate was $18.8 \%$ among females as against merely 5.2\% among males (GOK 2021). The disinclination towards engagement in agriculture and other conventional occupations and an aspiration towards white-collar jobs have further exacerbated the unemployment rates among the educated (GOK 2021). Nevertheless, these factors have not very much affected the conventional gender roles, with the result that larger proportions of women, even if educated, being confined to their homes without much income earning opportunities.

Despite the prevalence of higher unemployment rates, labour force participation rate among females seemed to be quite low in Kerala. For instance, the periodic labour force survey examining women participation in economic activities revealed that only $35 \%$ of women in the working age group (15-59 years) did participate in the labour market against 78\% among men during 2018-2019 (GOK 2021). In fact, such a lower work participation among females is in sharp contrast with very high levels of female work participation being reported from the southeast Asian countries, such as Thailand, the Philippines and Indonesia (Viswanathan and Thongthai 2009). Furthermore, women seemed to be under-represented in different levels of employment in the formal government sectors. For instance, the percentage of female employees in the government jobs was $35 \%$ with differences in their share in state government jobs (40\%) as against $24.5 \%$ in central government jobs during 2019-2020 (GOK 2021). Apparently, policymakers seemed to be less sensitized or not interested in addressing the issues related to women's upward mobility or developing mechanisms that can provide women with better access to market spaces or in starting an entrepreneurial venture (Mukhopadhyay 2007). Apart from these elements, the conservative attitude of the family members had also acted as roadblocks in women's mobility and growth in the state.

Though Kerala has been well known for the active trade union movements, women's representation in the workforce as well as trade unions in the organised sectors remained marginal, and their views were not considered while making decisions related to crucial aspects such as equality in wages. The lack of employment opportunities in Kerala had resulted in the outward migration of women, with a large number of them moving to West Asia and settling in occupations that did not provide job security with standard wages and social protection. The Kerala Migration Survey (KMS) reported that there has been a notable increase in the number of women emigrants in the middle east during 1999-2004 (Rajan 2004). The rise in emigration was $124 \%$ among the females as against $24 \%$ among the males. It was further reported that there were 0.39 million female emigrants in 2004 as against 1.53 million male emigrants, with women constituting little more than $20 \%$ of the total (Firstpost 2021). Yet another but major factor that reinforced the need for empowering women has been the historic deprivation of rights over land. As noted, women belonging to upper castes enjoyed high social status in the matriarchal society, along with ownership of land. However, in reality, these lands were used as dowry, on which women did not have much control. Land ownership was almost non-existent in case of socially and economically backward communities, who suffered discrimination the most (India Planning Commission 2008).

In Kerala, the questions of women's empowerment and participation in decision making become highly contested when it comes to their political representation and governance of the state administration. Though higher percentages of women participate as electors in the elections at the national (66\%) level, women's representation in the national Parliament and the state Legislative Assembly continues to be abysmally low. For instance, women constituted only $12 \%$ of the total Members of Parliament at the 16th Lok Sabha, with only one-woman MP (5 per cent) represent in the national Parliament from Kerala (GOK 2021). This is another major aspect that highlights the need for women's empowerment in the political sphere in Kerala. In this regard, it is important to note that the need for representation of women in the local governance has been gaining wider acceptance in the state with the state government making an enactment of one-third representation of women in the local bodies. Nevertheless, it is observed that women who get elected to local government bodies have to succumb to pressure wielded by their male 
counterparts and have resigned from their positions (Kannan 1999). Often, these female representatives are the kith and kin of those male political leaders. Thus, it may be observed that, despite being a progressive state, women do not get ample opportunities for being part of the governments at the national and state levels as well as the local administration. Obviously, all of the above factors reiterate the increasing need for women's empowerment in a highly progressive state, like Kerala.

\section{Method}

We opted for a qualitative approach, especially, a descriptive case study about the Kudumbashree program, which can be aptly considered as the largest women's movement in India. The Kudumbashree case allows for fine grained insights into the evolution of a rural women's empowerment program and the governance processes involved and successfully developed over time (Yin 2014). Kudumbashree also provides a longitudinal perspective of empowerment in rural context, which is an important justification for the application of qualitative approaches (Miles and Huberman 1984). We document the evolution and development of Kudumbashree over a time span since its inception in 2006 to date. The Kudumbashree Mission is an initiative by the Government of Kerala (GOK) to empower women and alleviate problems connected to food security and poverty. Kudumbashree, to date, is a 4 million active statewide network of women's groups engaged in various activities for their livelihood. The data and information gathered for the paper involved the use of multiple sources of documented material, such as reports from different stakeholders involved in the project (e.g., Kerala state, progress reports, newspaper articles, published research papers, extant literature on empowerment and entrepreneurship as well as on the role of governance in development missions, also guided our study and data analysis. We also had few interactions with the women representatives from Kudumbashree as regards the local engagements, the sources of economic dynamism and the future challenges facing the program.

\subsection{Case Study: Kudumbashree Mission}

(Kudumbashree had its origin as an urban poverty alleviation scheme in the Alappuzha municipality in Southern Kerala in the early 1990s, which later was developed as an initiative for identifying the poor households by using a deprivation index and then targeting rural women for organising for poverty eradication through constitution of 'mutual help societies'. In 1998, the government of Kerala (GoK) decided to implement all its anti-poverty programs through the Kudumbashree network and set up the state poverty alleviation mission (SPEM) as a government support system to the Kudumbashree units in the state. In 2011, Kudumbashree was also designated as the nodal agency for implementing the National Rural Livelihood Mission (NRLM) in the state. Currently, Kudumbashree is involved in a variety of activities related to poverty alleviation and well-being of the state, which are being implemented with the active involvement and collaboration from the gram (village) panchayats, which are grassroots level governance units (Kudumbashree 2019).

When launched, the program's mission was to eradicate absolute poverty in Kerala within a planned period of 10 years, led by the Local self-government (LSG) department, and with the support of the federal government of India (GOI) and in collaboration with the National Bank for Agriculture and Rural Development (NABARD). Kudumbashree is among the largest empowerment programs in India, covering 3.7 million members and $50 \%$ of all households in Kerala (Asian Development Bank 2015). The mission operates through community-based organizations, e.g., neighborhood help groups (NHG) covering women below the poverty line (an economic indicator), and act as an interface between governmental institutions and impoverished individuals. Kudumbashree is working on the understanding that empowerment is an ongoing evolution, which follows a process approach to development (Kudumbashree 2020). This philosophy perceives poverty and marginalization of women not as a financial issue, but as a deprivation of fundamental 
human rights. Thus, besides economic empowerment, Kudumbashree works on giving marginalized women a voice and helping them to organize as collectives to claim their rights, notably, by increasing women's participation in decision-making and enhancing local governance and leadership (Kudumbashree 2020). Empowerment initiatives also include women's capacity building through training and education, skill development, microfinance and the promotion of microenterprises (Asian Development Bank 2015).

\subsection{Evolution of the Multi-Actor Approach for Kudumbashree}

Kudumbashree applies a similar organizational structure as Kerala's community-based nutrition program (CBNP), which dates back to 1991. The CBNP initiative based on a three-tiered structure, comprised of neighborhood groups (NHGs), coalesced into more significant Area Development Societies (ADS) at the ward level of the panchayats (the macro faction of local self-governance units). These entities were further coalesced into Community Development Societies (CDS) at the municipal level. CBNP applied UNICEF's triple-A iterative process of repeating cycles of problem assessment and analysis and problemsolving actions that was regularly improved and modified (UNICEF 2021). It also involved participation from people in the lower strata, to plan, mobilize resources and finally deliver programs in partnership with the government. This led to the emergence of a community development system (CDS) with a distinct set of laws and procedures for running its daily operation and administration (Gopalan et al. 1995). Table 1 presents a snapshot of major milestones in the evolution and development of Kudumbashree over time.

Table 1. Major milestones in the evolution of Kudumbashree in Kerala (1991-2020).

\begin{tabular}{|c|c|}
\hline Date & Milestones \& Description \\
\hline 1991 & $\begin{array}{l}\text { Government of Kerala launched a community-based nutrition program (CBNP): Objective was to improve } \\
\text { nutritional levels of children and women. }\end{array}$ \\
\hline 1993 & $\begin{array}{l}\text { Establishment of community development society (CDS) system at Alappuzha and Malappuram: Alappuzha } \\
\text { Municipality established CDS in 1993. National Bank for Agriculture and Rural Development (NABARD) agrees to } \\
\text { refinance bank loans to NHGs. CDS system was formed in } 94 \text { Gram Panchayats and five Municipalities in } \\
\text { Malappuram district. }\end{array}$ \\
\hline 1994 & Alappuzha Model extended to all five Municipalities and 94 Village Panchayats in Malappuram district. \\
\hline 1995 & The CDS network was extended to cover all 58 Municipalities in the state. \\
\hline 1996 & $\begin{array}{l}\text { The Ministry led by the Left Democratic Front (LDF) launches Peoples Plan Campaign in Kerala that triggers people } \\
\text { participation in local development process. }\end{array}$ \\
\hline 1997 & $\begin{array}{l}\text { A Task Force of the Government presents a report to extend the Alappuzha Model to the entire State under the } \\
\text { name, Kudumbashree }\end{array}$ \\
\hline 1998 & $\begin{array}{l}\text { State Poverty Eradication Mission (SPEM) registered under the Travancore-Cochin Literary, Scientific and } \\
\text { Charitable Societies Act 1955. Thus, Kudumbashree Mission becomes a legal entity in the state. }\end{array}$ \\
\hline 1999 & $\begin{array}{l}\text { State Urban Poverty Alleviation (UPA) Cell wound up; SPEM declared State Urban Development Agency (SUDA). } \\
\text { Kudumbashree Mission becomes the nodal agency for urban poverty alleviation projects. }\end{array}$ \\
\hline 2000 & $\begin{array}{l}\text { Kudumbashree Mission Office set up in June and chalks out a 3-phase plan to form Kudumbashree CDSs in all } \\
\text { Panchayats (based on NHGs). CDS system extended to } 262 \text { Gram Panchayats, which were selected based on their } \\
\text { performance in the People's Plan campaign. }\end{array}$ \\
\hline & Initiates training and other assistance schemes for starting Micro Enterprises by Kudumbashree women \\
\hline 2001 & $\begin{array}{l}\text { The new government led by the United Democratic Front (UDF) assumes office. CDS system further expanded to } \\
\text { cover } 338 \text { more Gram Panchayats, along with new guidelines. }\end{array}$ \\
\hline 2002 & $\begin{array}{l}\text { CDS system launched in } 291 \text { more Gram Panchayats. Kudumbashree assists the government in identifying } \\
\text { beneficiaries under its Ashraya Scheme (care of the destitutes). }\end{array}$ \\
\hline 2003 & $\begin{array}{l}\text { CDS system was extended to cover the entire state of Kerala. Joint Liability Groups (JLGs) started to encourage } \\
\text { Kudumbashree women's groups to take up agriculture in leased in land. }\end{array}$ \\
\hline 2005 & $\begin{array}{l}\text { Government takes major policy decisions: (a) Implementation of the NREGS only through Kudumbashree; (b) } \\
\text { Formation of exclusive SC and ST NHGs wherever feasible. }\end{array}$ \\
\hline
\end{tabular}


Table 1. Cont.

\begin{tabular}{cl}
\hline Date & \multicolumn{1}{c}{ Milestones \& Description } \\
\hline 2005 & $\begin{array}{l}\text { (a) State launches national rural employment guarantee scheme (NREGS); (b) Promotes Bala Sabhas of } \\
\text { Kudumbashree children; (c) Micro Enterprises formed to supply nutritional food to all ICDS centres; (d) Initiates } \\
\text { setting up of BUDS Schools. }\end{array}$ \\
New government led by LDF assumes office. Kudumbashree women demands more autonomy and elections at all \\
levels, i.e., NHG's; ADS; CDS) \\
State government issues orders integrating SHGs under Swarnajayanthi Gram Sswarozgar Yojana (SGSY) with \\
2007 & $\begin{array}{l}\text { Kudumbashree. End of dual membership of poor families in SGSY SHGs and Kudumbashree NHGs. } \\
\text { Kudumbashree adopts Common Bye-Law for all CBOs. First election of Kudumbashree office bearers takes place. }\end{array}$ \\
2008 & $\begin{array}{l}\text { Launches Gender mainstreaming and Integration programmes. } \\
\text { UDF forms a new Government. Kudumbashree holds the Second election of office bearers for CBOs. }\end{array}$ \\
2011 & $\begin{array}{l}\text { National Rural Livelihood Mission (NRLM) selects Kudumbashree as its state level nodal agency. } \\
\text { Revised Election Guidelines: Secret ballot system replaces election through consensus at the general body meetings } \\
\text { of the community organisation. Third election of office bearers within the Kudumbashree CBOs }\end{array}$ \\
2014 & $\begin{array}{l}\text { LDF forms new government in the state. } \\
\text { Kudumbashree Mission starts to work with Haritha Karma Sena Project based on government order (GO number: }\end{array}$ \\
2017 & $\begin{array}{l}\text { 2420/2017-LSGD). This along with Suchitwa Mission and Clean Kerala Company work towards a garbage-free } \\
\text { Kerala. The powers to select Haritha Keralam Sena are vested with the local bodies. }\end{array}$ \\
& $\begin{array}{l}\text { Kudumbashree focused on formation of special NHGs for addressing the specific needs of vulnerable } \\
\text { communities/groups. 15,794 elderly NHGs (1.8 lakh members), 11 transgender NHGs (128 members) and 1610 } \\
\text { NHGs (13,077 members) for persons with disability (PWD)were formed till 30th September 2019. }\end{array}$
\end{tabular}

Source: Modified by authors based on: Kudumbashree (2021), Available online: https://thekudumbashreestory.info/index.php/historyand-evolution/kudumbashree-through-years (accessed on 15 March 2021); Kannan and Raveendran (2017).

A unique feature of CDS was the thrift and credit society (TCS), a microfinance scheme that later became the basic thrust of Kudumbashree to address poverty (Kudumbashree 2021). TCS was supported by the NABARD credit initiative, which also organized training for TCS women officials. Though the CDS model of governing development was an urban based initiative, it was later replicated successfully in rural areas. The efficacy and effectiveness of those pilot programs motivated the government to scale up the approach and apply the CDS approach throughout the state (in 19 different departments) under the Kudumbashree (Venugopalan 2014).

\subsection{The Working Model of Kudumbashree: The Role of Multiple Actors}

Multiple actors, especially the local government bodies, national and state governments, are actively engaged with Kudumbashree in implementing the various developmental programs.

\subsubsection{State Actors}

The Government of Kerala (GOK) has constituted the State Poverty Eradication Mission (SPEM). The mission was placed under the department of Local Self Government (LSG). Various actors at the state level include the state government agencies or the various departments, such as agriculture, horticulture, rural development, revenue, labor welfare, etc., which implement programs aimed at the wellbeing of the rural households and farming communities, including women and other marginalized sections of the society.

\subsubsection{National and Federal State Actors}

The Government of Kerala could garner support from the Federal Government (The Government of India, GOI) and the National Bank for Agriculture and Rural Development (NABARD) to eliminate absolute poverty in Kerala in a planned period of 10 years. Thrift and credit societies are fundamental for the Kudumbashree program. Commercial banks are linked with Kudumbashree through NABARD. For instance, Kudumbashree joins hands with NABARD and the Bank of India for providing agricultural credit for about 3000 farming groups to pursue cultivation and other farming activities. 


\subsubsection{Local Actors}

Kudumbashree has a community-based organization $(\mathrm{CBO})$ of the poor that is set up by the local self-government. As stated, the $\mathrm{CBO}$ is structured along three tiers: neighborhood groups (NHGs), area development societies (ADSs) and the Community development societies (CDS).

NHGs are collectives of 15-20 women belonging to families below the poverty line. NHG meets on a weekly basis; each NHG has five volunteering office bearers responsible for the coordination of various functional areas, such as income generation, community healthcare, education and others. Meetings are held at the houses of NHG members. NGH act also as thrift and credit societies in order to serve the needs of the impoverished majority of society and include them into the financial system. A member can avail a credit up to four times their savings. Multiple studies have reported that easy availability and access to credit as the rationale for women's participation in NHGs (Kadiyala 2004; Kannan and Raveendran 2017). This credit is mobilised through thrift collected from the members on a weekly basis. The amount collected is deposited into a bank, and these actions help enhance the disadvantaged group's competency to manage their finance prudently. The NHG's weekly thrift amount is decided and observed to be as low as Rs 50 (0.75 USD) per week. Major decisions are taken in the NHG meetings after reaching a consensus among members, instead of resorting to a voting mechanism (Siwal 2009). The thrift fund is utilized to finance NHG members' emergency needs including medical expenses. A member is eligible to avail a loan amounting to four times of their investment in the thrift credit society. The community members determine the loan amount in a transparent and democratic manner, and loan requests are processed based on the seriousness of the matter for which fund is sought for. While this presents the humanitarian dimension of the thrift credit society, due diligence is also taken to assess the repayment ability and credibility of the member who is provided with internal loans. Over a period of time, Kudumbashree became an archetype for informal banks for the financially excluded lot and provided them with access to easy credit. Kudumbashree promotes NHGs of 10-20 poor women members as an interface between poor women, banks and government agencies. NHGs, in turn, act as instruments in thrift mobilization, encouraging the poor to save and to avail low cost formal credit. Thus, they facilitate easy and timely credit to the un-reached (GOK 2021).

The second level refers to area development societies (ADSs) that work at the urban/rural ward levels and federate all NHGs of the particular area, represented by elected NHG representatives. Finally, the Community development societies (CDS) at the Panchayath/Municipal level federates the different ADSs through their representatives in the local bodies. The CDS is wholly managed by women representatives and possesses the attributes of a nongovernmental organization, which facilitates garnering of additional resources from both internal as well as external sources. The CDS acts as the core liaison office with various governmental agencies and spearheads the various ADS and NHG operations.

\subsubsection{Convergence between Different Actors and Programmes}

The convergence between the democratic institutions and poor people-led CBOs is the innovative working model that evolved with Kudumbashree. Here, CBOs play a vital role in planning, implementation and monitoring of the developmental programs. The implementation of various socio-welfare schemes sponsored by both the national and state governments through this convergence mechanism has enabled active participation of the people and ensured access of the targeted sections to the particular benefits. In this regard, the various socio-economic welfare schemes function as the important platform for institutions of the poor to establish and strengthen themselves as agencies of empowerment (Kudumbashree-NRO 2014).

The aspirations of the poor presented in the NHG meetings give shape to micro plans, which are carefully scrutinised and incorporated into MINI plans at the ADS level. These mini plans are further consolidated at the CDS level and is integrated with the "anti-poverty sub-plan" of the local government, diligently monitoring the implementation 
of the plans. This allows the impoverished women to partake in the planning process as a major stakeholder. Kudumbashree is also designated as the state agency for urban development in Kerala, as well as a designated nodal agency for Federal Governmentsponsored programs for urban poverty alleviation such as Swarna Jayanthi Shahari Rozgar Yojana (SJSRY), National Slum Development Programme (NSDP). The leadership team of Kudumbashree ensures that there is an effective linkage between local governance bodies at multiple levels of its structure, at both ADS and CDS levels in implementing the various initiatives and activities launched.

The various programs implemented include the creation of microenterprises and lease land farming (LLF). The participation level in these activities has reached a new height due to the consistent efforts focused on improving local governing bodies' effectiveness without reducing CDS' decision-making power. A closer look at the number of women engaged in LLF reveals that there was notable increase (22.65\%) in the number from 2.35 lakhs during 2006-2007 to 3.34 lakhs during 2019-2020. On average, about 50,000 joint liability groups (JLGs) associated with the Kudumbashree have been constantly engaged into LLF involving an acreage of 40,000 ha over the past 15 years from 2005-2006 to 2019-2020 (Kudumbashree Report, 2019-2020). Like many other Kudumbashree projects, LLF activity may be considered as a distinct case of interaction between multiple agencies/institutions at various stages of farming. For instance, in the first stage, the Panchayat facilitates the provision of production implements, farm machinery, water supply and marketing support. Then, in the second stage, land preparation is done by employing workers (mostly women) who are enrolled into the national rural employment guarantee (NREG) program, implemented by the Ministry of Rural Development (MoRD). Thirdly, the Mahila Kisan Sashakthikaran Pariyojana (MKSP), a sub component of the National Rural Livelihood Mission (NRLM) provides orientation to the women JLG members in farming, skill development and dissemination of farming practices. In the next step, the Agriculture Department (GoK) provides state crop insurance as well as technical support. Then, the NABARD provides a subsidy at low interest rates, while the commercial banks provide crop loans and the private insurance companies extends the crop or weather insurance schemes as applicable.

Further convergence mechanisms include collaborative agreements between Kudumbashree and several government departments and nodal agencies to have an integrated mechanism to market and procure several items. It is observed that Kudumbashree led programmes are being implemented in convergence with more than 30 government agencies, representing the national and state governments. To name a few, some of these agencies include the Spices Board, the Khadi and Village Industries Board, the Industries Department, Social Welfare Department, Women and Child Department, Suchitwa Mission, Social Justice Department, etc. The above institutional arrangements have helped the mission to reach out to fulfill the various needs of its member units and the program beneficiaries. Figure 1 provides a pictorial representation of the planning activity at the grassroots level and various schemes' execution in convergence with various agencies.

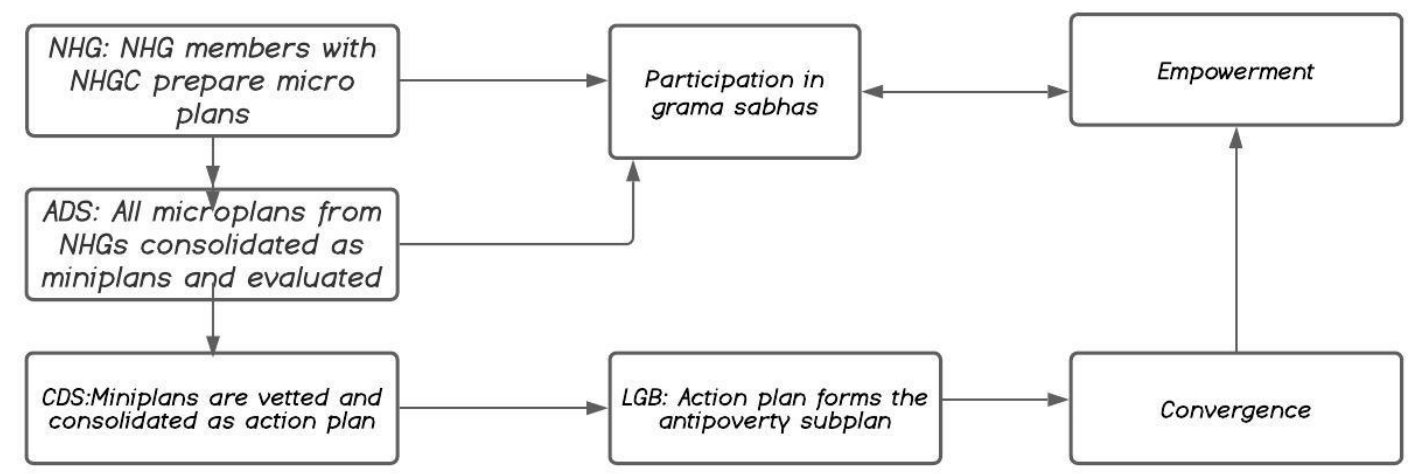

Figure 1. Community Based Organization process of decision making. Notes: NHG = neighborhood group; NHGC = neighborhood group committee; $\mathrm{ADS}=$ Area Development Society; $\mathrm{CDS}=$ Community Development Society; LGB = local governing bodies. 


\subsection{Micro-Enterprises: Key to Empowerment}

Kudumbashree has chosen a strategy of economic empowerment through micro-enterprises, which represents the pivotal tenet in the empowerment strategy of the underprivileged and marginalized people. In this regard, Kudumbashree has worked in unison with various governmental departments and NABARD to develop an entrepreneurial culture among NHGs. Kudumbashree offers access to finance for small companies, trainings, marketing support and sees micro-entrepreneurs through their entrepreneurial process and monitors their activities and supports them in their business (Kudumbashree 2021). The program has been successful in establishing 193,676 economic ventures including non-agriculture based enterprises across the state, which include 64,219 group ventures/enterprises and 129,457 individual ventures/enterprises. Among the various micro-enterprises, $39,828(20.6 \%)$ engage in crop production, 75,880 (39.2\%) in livestock/dairy production, 42,150 (21.7\%) in manufacturing activities, and 27,657 (14.3\%) operate in trade, and the rest in services activities, including transport and restaurants (Kannan and Raveendran 2017).

The micro-enterprise ecosystem is very diverse and includes an array of activities, viz., catering services, courier services, e-governance kiosks, food processing; fitness studios, lease-land farming, pharmacies, tailoring units, transportation and many more. The Kudumbashree mission encourages local production and promotes the consumption of local products. Volunteers routinely carry out market analysis and research the design and development of new products and services. Moreover, Kudumbashree's enterprises have generated new employment opportunities for marginalized people. A case in point here is the responses of Kudumbashree during the Covid-19 pandemic period. When the State government had announced a 100-day action plan for mitigating the sufferings faced by the people due to Covid-19 pandemic, Kudumbashree provided jobs and self-employment opportunities to 15,000 persons within 100 days. Of the 13,347 enterprises established, the majority was for self-employment $(11,405)$, followed by wage employment $(1942)$. The employment further increased to 23,606 (Self-Employment: 21,735; Wage Employment: 1871) up to 10 November 2020 (GOK 2021).

\subsection{Economic, Financial and Social Pillars of Empowerment}

Most women were drawn to the program because different NGO's as well as representatives of the mission itself, and representatives of Kudumbashree engaged with them and promoted the benefits of participation to them (Siwal 2009). Empirical research has identified several motivators for women to become participants in the Kudumbashree program. The improvement of their economic situation, which would lead to greater financial security and help improving their social status, was one of the strongest motivators (Siwal 2009).

Kannan and Raveendran (2017) present a diverse set of reasons why women liked to participate in the program. The most important went beyond economic considerations. Kudumbashree (a) enabled women to achieve personal goals; (b) taught women about their personal rights and duties; (c) provided women with the possibility to express speak publicly; (e) supported and enabled women to claim government services; (f) provided them with the possibility to participate in Panchayat functions; (g) enabled women to participate in meetings and to freely express the own views; (h) improved women's self-esteem; (i) provided them with travel experience outside their district; (j) enabled them to participate in political processes. Women also had a strong desire to contribute to community development and feel that they are part of Kerala's social and economic development process. The SHG has impacted 43 lakh families and empowerment attainment by women has enhanced their role in the family decision-making process (Reheem 2013). NHG's credit to women members in BPL families' for developing amenities has changed men's attitude towards their partners. It allowed them to express their opinion on children's education by deciding on the day's meals and availing health care options (Raghavan 2009). The supplementary income source earned them a formidable position among family members and recognized their work (Devika and Thampi 2007; Santhosh 2012). Sanyal (2009) opines that Kudumbashree mission activities have helped the marginalized women to create a 
social network that is homophilous and foster their political participation. Furthermore, the NHG volunteers encourage the weaker section of women's society to engage in various social activities actively and boost their self-efficacy and self-worth (Selvi and Pushpa 2018). A similar observation has been made by Varghese (2012) on the empowerment of women through the program. The extant literature also bolsters the above arguments that the linkages created through various activities reinforce the pre-eminence of the SHGs/NHGs members in enhancing the level of social participation (Bandhyopadhyay et al. 2002). The various initiatives adopted at the grassroots level have helped the Kudumbashree mission volunteers to create a positive attitude in their members' minds and establish a healthy social relationship (Arun et al. 2011). Reheem (2013) notes that involvement of women into local governance coupled with their stronger economic positions was empowering as it also signifies social change because of their improved social positions in conservative male-dominated family settings.

Nevertheless, though the literature is abundant with studies about the positive impacts, the Kudumbashree mission has been criticized for failing less educated women in remote rural areas (Venugopalan 2014), in smaller segments of ethnic minorities, such as Muslims (Kannan and Raveendran 2017), and among tribal people (Nithya 2013), which tend to have weak social interactions beyond their close tribal networks (Sachana and Anilkumar 2015). Williams et al. (2011) also raised concerns that women's public participation is often constrained by the lack of autonomy of the 'invited spaces' it has created and the underlying concept of poverty alleviation it embodies.

From the discussions as well as the literature reviews presented in the foregoing, we take a moderate to stronger view that Kudumbashree initiatives have been quite successful in terms of strengthening the stake of women in the state through empowerment which assumed a multi-dimensional character as presented in Figure 2.

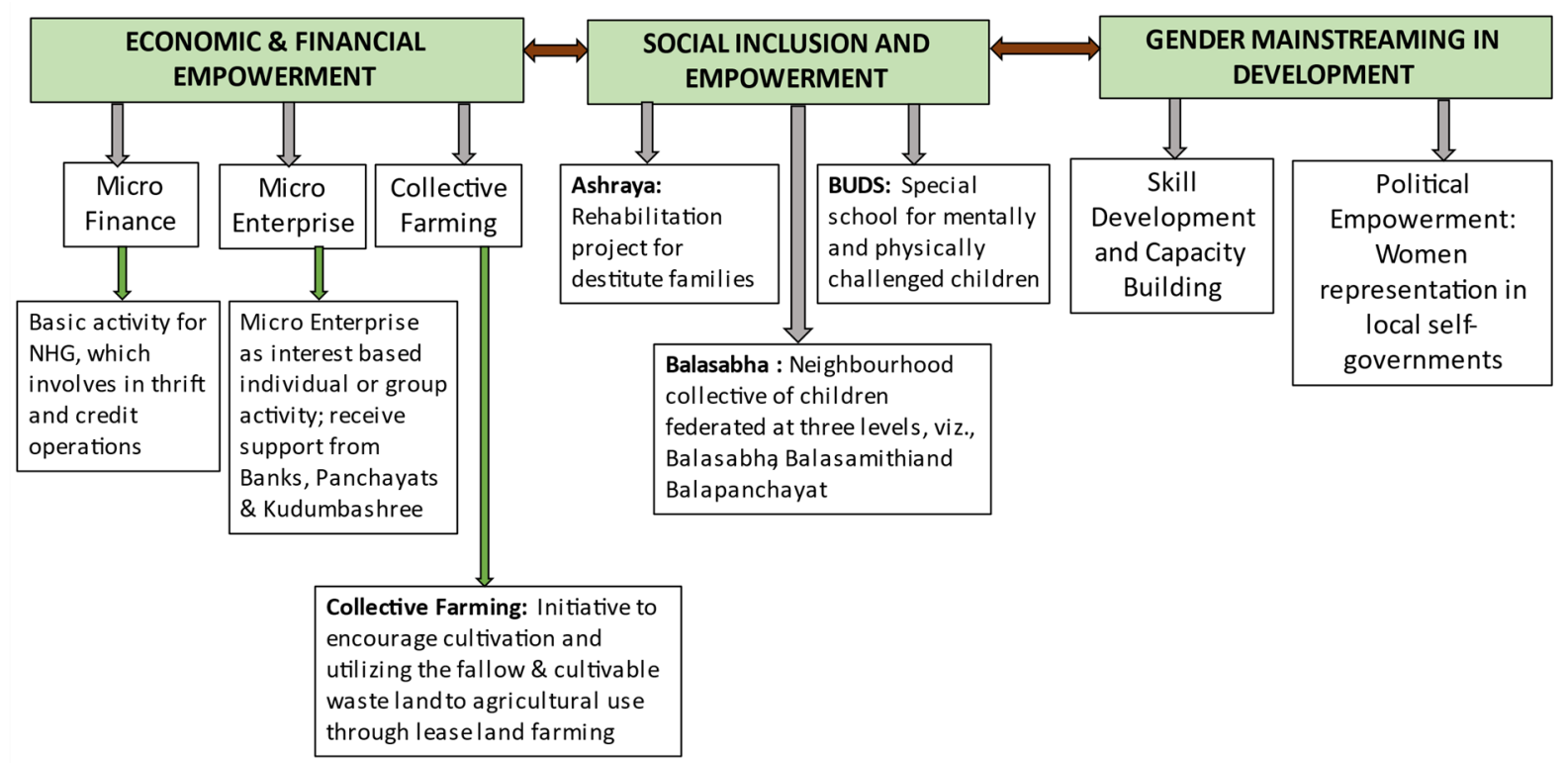

Figure 2. Kudumbashree and multi-dimensional empowerment.

We also present here the most recent evidence depicting the physical and financial status of achievement of various social as well as economic development and empowerment initiatives under Kudumbashree in Kerala (Tables 2 and 3). 
Table 2. Key components of Kudumbashree programme-Physical achievement, 2019-20.

\begin{tabular}{llc}
\hline \multicolumn{1}{c}{ Physical Components } & No/Quantity * \\
\hline 1. No of NHGs & $2,87,723$ \\
2. No. of NHG Members & $4,51,0000$ \\
3. & Transgender groups (Nos.) & 19 \\
4. & Differently abled (disabled) Person Groups & 754 \\
5. & Elderly Groups (Nos) & 2123 \\
6. & Women Micro Enterprises (Nos) & 87,239 \\
7. No of JLGs & 71,572 \\
8. No of JLG members & $3,54,122$ \\
9. Women JLGs (agriculture) & 50,620 \\
10. Lease Land Farming (Hectares) & 43,744 \\
11. $\quad$ Ashraya Destitute Rehabilitation project (no of families) & 174,443 \\
12. $\quad$ BUDS schools (for mentally challenged students) & 3 \\
13. Tailoring units & 359 \\
14. $\quad$ IT Units \& Survey Team\# & 63 \\
15. $\quad$ Railways (Parking and Waiting hall management) & 40 Stations \\
16. $\quad$ Metro station management (Nos.) * & 70 \\
17. $\quad$ Vulnerability mapping done (No of Panchayats) & 140 \\
\hline Note: \# For implementation of pension and other schemes; ${ }^{*}$ including transgenders. Source: ${ }^{*}$ Compiled from \\
Reports of Kudumbashree (https://kudumbashree.org/) [Compiled\}.
\end{tabular}

Table 3. Key components of Kudumbashree programme-Financial achievement, 2020-21.

\begin{tabular}{lcc}
\hline \multicolumn{1}{c}{ Component } & Amount (Rs. Million) & (\%) Share \\
\hline I. Social Development \& Empowerment & & \\
(a) Destitute Free Kerala & 514.04 & 46.19 \\
(b) BUDs & 18.65 & 1.68 \\
(c) Balasabha & 2.26 & 0.20 \\
(e) Gender Education and women empowerment & 27.15 & 2.44 \\
(f) Tribal Development & 15.98 & 1.44 \\
Sub Total & 578.08 & 51.95 \\
II. Local Economic Development \& Empowerment & & 0.00 \\
(a) Microfinance & 359.14 & 32.27 \\
(b) Micro Enterprise Activities & 18.22 & 1.64 \\
(c) Agricultural Activities & 124.82 & 11.22 \\
(d) Animal Husbandry activities & 19.19 & 1.72 \\
(e) Marketing development & 13.32 & 1.20 \\
Sub Total & 534.69 & 48.05 \\
Grand total & 1112.78 & 100.00 \\
\hline Note: Source: ${ }^{*}$ Compiled from the Reports of Kudumbashree (https://kudumbashree.org/).
\end{tabular}

\subsection{Multi-Actor Engagement Model for Successful Empowerment}

The case study of Kudumbashree reveals key drivers related to the women's empowerment programs and their sustenance in Kerala, which will be addressed and discussed in the following. Our model of the Kudumbashree multi-actor engagement approach for women empowerment is depicted as an inverted pyramid as presented in Figure 3 . The central elements for the success of Kudumbashree include strong involvement of the Kerala state government in the program and the bottom-up approach to empowerment creates participatory spaces for marginalized women and their families. 

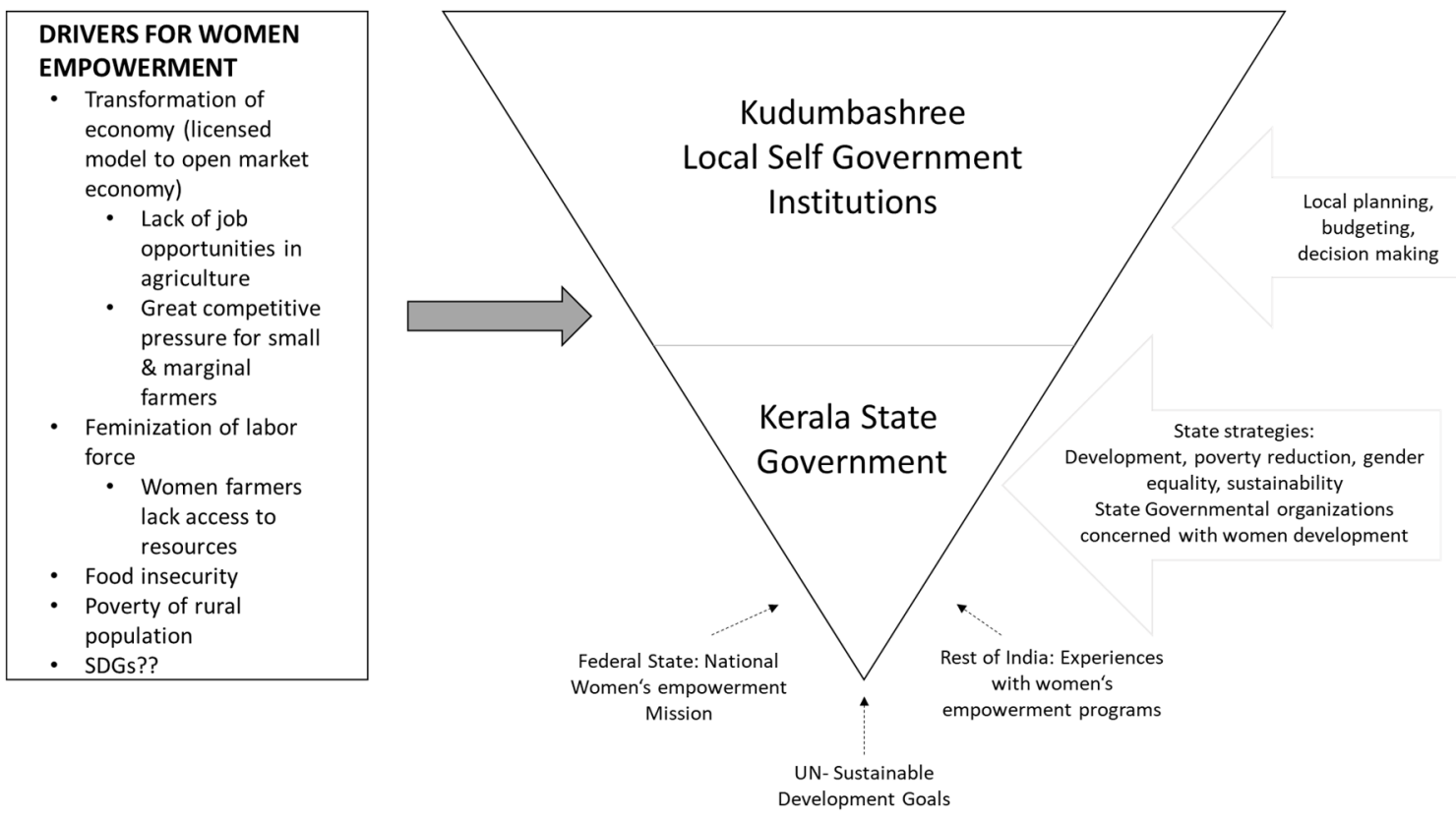

Figure 3. Inverted pyramid of multi-actor engagement framework model for women empowerment.

\subsection{Ownership-Role of the State Government for Women Empowerment}

As our case study shows, the government of Kerala actively supports a multi-actor engagement approach, which favors local self-government and bottom-up approaches to development. The Kudumbashree case reveals the contextualization of empowerment planning within institutional frameworks and the importance of state governmental women's machineries and development policies to push and to promote female empowerment through entrepreneurship. Pivotal for the facilitation of social change has been the introduction of a gender strategy within Kerala's poverty eradication mission. Moreover, activities of the Kudumbashree program were interlinked with diverse government bodies and nodal agencies on state and national level, which provided access to important resources. Collaboration mechanisms (mainly through mission coordinators and community organizers) feature prominently the centrality of governance structure and operations aligned with a concerted effort regarding women's empowerment for social change.

The Kerala state government has taken ownership for a gender and development program, which emphasizes women's empowerment through capability development and involvement in the governance decision making. In this way, empowerment goes beyond economic development because it seeks to provide women with control over strategic life choices (Kabeer 1999) through engagement in Kudumbashree's organization, as well as through political engagement that has impact beyond the Kudumbashree mission. The ownership role of the state government is very important for concerted actions as well as for the acceptance of women agency and mobilization as a motor for social change in society.

\subsection{Decentralization of Decision Making in Favor of Local Governance and the Creation of Open} Participation Spaces

The Kudumbashree program displays a complex system of decision-making and power "sharing" that includes formal state institutions/authorities, as well as local community actors and women (groups). By deliberately assigning decision power to NHGs, as well as local committees and others (e.g., community development societies, area development societies, etc.), Kudumbashree intentionally convenes local actors and governance entities to cooperate in decision-making. Here, the program is also sensitive not just to local needs, but to invisible forms of power (Gaventa 2006) that reside within culture, customs and traditions that are often impeding female agency. Involving and engaging "locals" into decision-making moves the subject of gender equality into a larger community/society 
context with the potential to influence and change prevailing ideas regarding the role of women in society (Rowlands 2016) and, by this shift, invisible power in favor of women. Decentralized planning enables the creation of a social platform for women and marginalized families to represent their needs, determine their communities' goals, and take it to the next level, because the demands that evolve out of Kudumbashree meetings are passed on to various state agencies and public institutions to take policy actions.

Therefore, Kudumbashree not only represents a development program, but a space for citizen participation (Thorpe and Gaventa 2020). Gaventa (2006) shows that such participation spaces are never neutral grounds and are always a reflection of existent power dynamics (depending who created the space for what reason). However, with Kudumbashree, the government of Kerala has created an arena for public involvement (Thorpe and Gaventa 2020) where marginalized women participate in diverse political and economic institutions and through this are encouraged to take responsibility for their life and their community (local and state). Participatory spaces and participatory governance (planning, budgeting, resource deployment, etc.) provide the chance to generate transformative social changes beyond individual emancipation, which is central to the definition of empowerment (Calas et al. 2009), or, as Gaventa (2006) formulates, when social actors "are able to link the demands for opening previously closed spaces with people's action in their own spaces; to span across local and global action, and to challenge visible, hidden and invisible power simultaneously" fundamental social changes can happen that overcome structures, which legitimized women's submission and marginalization (Batliwala 2007) before.

\section{Conclusions}

Based on an in-depth case study of Kudumbashree, a program that has already been identified as one of the global best practices for poverty eradication and women's empowerment (Devika and Thampi 2007), we analyzed the role of multiple agencies in fostering social inclusion and greater women participation and the eventual success of Kudumbashree empowerment projects. We find that the multi-actor engagement strives for an equilibrium between social change through policy and regulatory change (top down) and social change via mobilizing the people (bottom-up). Nevertheless, our study outcomes should be viewed in the light of its limitations as well. We use Kudumbashree as a single case study and empirical support, which limits the generalizability of its findings. However, there is ample evidence that support empowerment approaches, which focus predominantly on an individualized empowerment related to economic independence that do not necessarily fit the developmental context and conditions. Previous research shows that the focus on bottom-up approaches only could lead to substantial positive transformation for individuals, but does not necessarily lead to social change (Al-Dajani and Marlow 2013). However, having a multiple actor approach where the government takes active ownership for gender equality and development coupled with a decentralized approach to decisionmaking that favors local (women) based governance was shown to lead to transformational change regarding gender relations in a highly gendered society. Multi-governance models seem most adequate for the cause due to the multi-layered nature of female empowerment and its intersecting cultural, social and economic dimensions. The Kudumbashree program addresses women's educational and economic abilities (including their access to important resource, e.g., finance, human, networks), as well as women's active engagement in community, local and regional institutions empower them politically. As such, Kudumbashree's governance approach allows for developing individual agency, as well as its collective female agency to facilitate social change. From a policy angle, the key learnings from the successful outcomes of Kudumbashree may be considered for designing rural and urban community development programs across states in India with a focus on the multidimensional empowerment of women and the marginalized communities. However, the ultimate success from the emulation of the Kudumbashree induced development initiatives in the rest of the Indian states would call for restructuring and strengthening of the local governance systems and other stakeholders, including community-based organizations. We also 
consider that the paper makes a unique contribution to academic and action research on women empowerment outcomes from the perspective of the Global South that might help further research in this area. Based on the findings of the study, we also identify the future research and policy gaps that could address the potential implications of Kudumbashree programs on women empowerment outcomes as aligned with the UN sustainable development goals (SGDs) related to gender equality (SDG5), reduced inequalities (SDG10), good health and wellbeing (SDG3) of women and marginalized communities in Kerala.

Author Contributions: Conceptualization: M.V.; methodology: M.V., B.L.B., P.K.V.; validation: M.V., B.L.B., P.K.V.; formal analysis: M.V., B.L.B., P.K.V.; investigation: M.V., B.L.B., P.K.V.; writing—original draft preparation: M.V., B.L.B., P.K.V.; writing—review and editing: M.V., B.L.B., P.K.V.; visualization: M.V., B.L.B., P.K.V.; project administration: M.V., B.L.B., P.K.V. All authors have read and agreed to the published version of the manuscript.

Funding: This research received no external funding.

Informed Consent Statement: Not applicable.

Conflicts of Interest: The authors declare no conflict of interest.

\section{References}

Adjei, Stephen B. 2015. Assessing women empowerment in Africa: A critical review of the challenges of the gender empowerment measure of the UNDP. Psychology and Developing Societies 27: 58-80. [CrossRef]

Al-Dajani, Haya, and Susan Marlow. 2013. Empowerment and entrepreneurship: A theoretical framework. International Journal of Entrepreneurial Behaviour \& Research 19: 503.

Alsop, Ruth, Mette Bertelsen, and Jeremy Holland. 2005. Empowerment in Practice: From Analysis to Implementation. Washington: The World Bank. [CrossRef]

Anderson, Alistair R., and Monica D. Lent. 2017. Enterprising the rural: Creating a social value chain. Journal of Rural Studies 70: 96-103. [CrossRef]

Arun, Shoba, Thankom Arun, and Usha Devi. 2011. Transforming livelihoods and assets through participatory approaches: The Kudumbashree in Kerala, India. International Journal of Public Administration 34: 171-79. [CrossRef]

Asian Development Bank. 2015. Gender Mainstreaming Case Study India. Kerala Urban Sustainable Development Project. Available online: https://www.adb.org/sites/default/files/publication/160695/gender-mainstreaming-ind-kerala-urban.pdf (accessed on 4 March 2021).

Avelino, Flor, and Julia M. Wittmayer. 2016. Shifting power relations in sustainability transitions: A multi-actor perspective. Journal of Environmental Policy \& Planning 18: 628-49.

Bandhyopadhyay, D., B.N. Yugandhar, and Amitava Mukherjee. 2002. Convergence of programmes by empowering SHGs and PRIs. Economic \& Political Weekly 37: 2556-61.

Bastian, Bettina L. 2017. Empowerment Against All Odds: Women Entrepreneurs in the Middle East and North Africa. In Entrepreneurship: Concepts, Methodologies, Tools, and Applications. Hershey: IGI Global, pp. 1975-87.

Bastian, Bettina, and Mohammad Reza Zali. 2016. The impact of institutional quality on social networks and performance of entrepreneurs. Small Enterprise Research 23: 151-71. [CrossRef]

Bastian, Bettina L., Beverly D. Metcalfe, and Mohamad R. Zali. 2019. Gender Inequality: Entrepreneurship Development in the MENA Region. Sustainability 11: 6472. [CrossRef]

Batliwala, Srilatha. 1994. The meaning of women's empowerment: New concepts from action. In Population Policies Reconsidered: Health Empowerment and Rights. Edited by Gita Sen, Adrienne Germain and Lincoln C. Chen. Harvard: Harvard Center for Population and Development Studies.

Batliwala, Srilatha. 2007. Taking the power out of empowerment-An experiential account. Development in Practice 17: 557-65. [CrossRef]

Brush, Candida G., Anne De Bruin, and Frederieke Welter. 2009. A gender-aware framework for women's entrepreneurship. International Journal of Gender and Entrepreneurship 1: 8-24. [CrossRef]

Calas, Marta B., Linda Smircich, and Kristina A. Bourne. 2009. Extending the boundaries: Reframing "entrepreneurship as social change" through feminist perspectives. Academy of Management Review 34: 552-69. [CrossRef]

Census. 2011. Census Population Extrapolated; New Delhi: Government of India.

Chesney, Barbara K., and Mark A. Chesler. 1993. Activism through self-help group membership: Reported life changes of parents of children with cancer. Small Group Research 24: 258-73. [CrossRef]

Craps, Marc, Inge Vermeesch, Art Dewulf, Koen Sips, Katrien Termeer, and René Bouwen. 2019. A relational approach to leadership for multi-actor governance. Administrative Sciences 9: 12. [CrossRef] 
Datta, Punita Bhatt, and Robert Gailey. 2012. Empowering women through social entrepreneurship: Case study of a women's cooperative in India. Entrepreneurship Theory and Practice 36: 569-87. [CrossRef]

De La Chaux, Marlen, Helen Haugh, and Royston Greenwood. 2018. Organizing refugee camps: "Respected space" and "listening posts". Academy of Management Discoveries 4: 155-79. [CrossRef]

Devika, J., and Binitha. V. Thampi. 2007. Between 'Empowerment' and 'Liberation': The Kudumbashree Initiative in Kerala. Indian Journal of Gender Studies 14: 33-59. [CrossRef]

Dreze, Jean, and Amartya Sen. 1995. India: Economic Development and Social Opportunity. New Delhi: Oxford University Press.

Dreze, Jean, and Amartya Sen. 2013. An Uncertain Glory: India and Its Contradictions. New Jersey: Princeton University Press.

Duflo, Esther. 2012. Women Empowerment and Economic Development. Journal of Economic Literature 50: 1051-79. [CrossRef]

Ennis, Crystal A. 2019. The gendered complexities of promoting female entrepreneurship in the Gulf. New Political Economy 24: 365-84. [CrossRef]

Escobar, Arturo. 1992. Imagining a post-development era? Critical thought, development and social movements. Social Text 31/32: 20-56. [CrossRef]

Firstpost. 2021. The Promised Land: Kerala's Female Emigrants Key Reason Behind Rise in Remittances. Available online: https: / / www.firstpost.com/long-reads/the-promised-land-keralas-female-emigrants-key-reason-behind-rise-in-remittances3730831.html (accessed on 4 March 2021).

Franke, Richard. 1993. Life Is a Little Better: Redistribution as Development in an Indian State. Boulder: Westview Press.

Gaventa, John. 2006. Finding the spaces for change: A power analysis. IDS Bulletin 37: 23-33. [CrossRef]

GOK. 2021. Economic Review 2020-21; Thiruvananthapuram, Kerala: State Planning Board, vol. 1, p. 718. Available online: https: / / spb.kerala.gov.in/economic-review /ER2020/ (accessed on 17 March 2021).

Gopalan, S., R. Bhupathy, and H. Raja. 1995. Appraisal of Success Factors in Nutrition Relevant Programs: A Case Study of Alappuzha Community-Based Nutrition Programme. Chennai: United Nations Children's Fund.

Hooghe, Liesbet, Gary Marks, and Arjan H. Schakel. 2020. Multilevel governance. Comparative Politics 5: $193-210$.

India Planning Commission. 2008. Kerala Development Report. Cambridge: Academic Foundation.

Isaac, Thomas. 2001. Campaign for democratic decentralisation in Kerala. Social Scientist 29: 8-47. [CrossRef]

Janssens, Maddy, and Jeanne M. Brett. 2006. Cultural intelligence in global teams: A fusion model of collaboration. Group E Organization Management 31: 124-53.

Kabeer, Naila. 1999. Resources, agency, achievements: Reflections on the measurement of women's empowerment. Development and Change 30: 435-64. [CrossRef]

Kabeer, Naila. 2005. Gender equality and women's empowerment: A critical analysis of the third millennium development goals. Gender and Development 13: 13-24. [CrossRef]

Kadiyala, Suneetha. 2004. Scaling up Kudumbashree Collective Action for Poverty Alleviation and women's Empowerment. Washington: International Food Policy Research Institute USA, May.

Kannan, K.P. 1999. Rural Labour Relations and Development Dilemmas in Kerala: Reflections on the Dilemmas of a Socially Transforming Labour Force in a Slowly Growing Economy. Journal of Peasant Studies 26: 140-81. [CrossRef]

Kannan, K.P., and G. Raveendran. 2017. Poverty, Women and Capability: A Study of the Impact of Kerala's Kudumbashree System on Its Members and Their Families. Thiruvananthapuram: Laurie Baker Centre for Habitat Studies, Available online: https: / / www.google.com.hk/url?sa=t\&rct=j\&q=\&esrc=s\&source=web\&cd=\&ved=2ahUKEwiYxrDxorbvAhWjyYsBHR1jA4 AQFjAAegQIARAD\&url=http\%3A\%2F\%2Fkudumbashree.org\%2Fstorage\%2Ffiles\%2F1yzdo_kshree\%2520full\%2520ms_ kpkcorrected\%2520with\%2520cover_08.11.17-1.pdf\&usg=AOvVaw3F9x64beqIf8ACBSDLMq7b (accessed on 15 March 2021).

Knüppe, Kathrin, and Claudia Pahl-Wostl. 2013. Requirements for adaptive governance of groundwater ecosystem services: Insights from Sandveld (South Africa), Upper Guadiana (Spain) and Spree (Germany). Regional Environmental Change 13: 53-66. [CrossRef]

Kudumbashree. 2019. Annual Plan 2019-20. Available online: https:/ / kudumbashree.org/pages/765 (accessed on 17 March 2021).

Kudumbashree. 2020. Kerala State Rural Livelihood Mission Day NRLM Annual Action Plan 2019-2020. Available online: qm0dp_ kudumbashreenrlmaap2019-20.pdf (accessed on 15 March 2021).

Kudumbashree. 2021. Kudumbashree. Available online: https:/ / www.kudumbashree.org/ (accessed on 4 March 2021).

Kudumbashree-NRO. 2014. Imagining Convergence Kerala Context $\mathcal{E}$ an Ideation Framework. Thiruvananthapuram, Kerala: Kudumbashree-National Resource Organization, August, 21p, Available online: https://www.kudumbashreenro.org/ resources/others/item/download/3_5f92507e2512b59aded65d53ca6cf9ce (accessed on 4 March 2021).

Kusters, Koen, Louise Buck, Maartje de Graaf, Peter Minang, Cora van Oosten, and Roderick Zagt. 2018. Participatory planning, monitoring and evaluation of multi-stakeholder platforms in integrated landscape initiatives. Environmental Management 62: 170-81. [CrossRef] [PubMed]

Mair, Johanna, Ignasi Marti, and Marc J. Ventresca. 2012. Building inclusive markets in rural Bangladesh: How intermediaries work institutional voids. Academy of Management Journal 55: 819-50. [CrossRef]

Malhotra, Anju, Sidney Ruth Schuler, and Carol Boender. 2002. Measuring Women's Empowerment as A Variable in International Development. Washington: The World Bank.

Miles, Matthew B., and A. Michael Huberman. 1984. Drawing valid meaning from qualitative data: Toward a shared craft. Educational Researcher 13: 20-30. [CrossRef] 
Mosedale, Sara. 2005. Assessing women's empowerment: Towards a conceptual framework. Journal of International Development 17: 243-57. [CrossRef]

Mukhopadhyay, Swapna, ed. 2007. The Enigma of the Kerala Woman: A Failed Promise of Literacy. New York: Berghahn Books.

Muntean, Susan C., and Banu Ozkazanc-Pan. 2016. Feminist perspectives on social entrepreneurship: Critique and new directions. International Journal of Gender and Entrepreneurship 3: 221-41. [CrossRef]

Narayan-Parker, Deepa, ed. 2005. Measuring Empowerment: Cross-Disciplinary Perspectives. World Bank Publications: Available online: worldbank.org (accessed on 4 March 2021).

Nawaz, Faraha. 2019. Microfinance and Women's Empowerment in Bangladesh: Unpacking the Untold Narratives. London: PalgraveMacmillan.

Nithya, N.R. 2013. Land question and the tribals of Kerala. International Journal of Scientific E Technology Research 2: 102-5. Available online: http:/ / www.ijstr.org/final-print/sep2013/Land-Question-And-The-Tribals-Of-Kerala.pdf (accessed on 15 March 2021).

Ojediran, Funmi O., and Alistair Anderson. 2020. Women's Entrepreneurship in the Global South: Empowering and Emancipating? Administrative Sciences 10: 87. [CrossRef]

Parwez, Shazzad. 2016. A Comparative Study of Gujarat and Kerala Developmental Experiences. International Journal of Rural Management 12: 104-24. [CrossRef]

Pratto, Felicia. 2016. On power and empowerment. British Journal of Social Psychology 55: 1-20. [CrossRef] [PubMed]

Raghavan, V.P. 2009. Micro-credit and Empowerment: A study of Kudumbashree Projects in Kerala, India. Journal of Rural Development 28: $478-79$.

Rajan, S. Irudaya. 2004. From Kerala to the Gulf: Impacts of Labor Migration. Asian and Pacific Migration Journal 13: 497-509. [CrossRef]

Reheem, S. 2013. A case study on Kudumbashree: Political empowerment of women for sustainable poverty reduction. International Journal of Sustainability in Economic, Social, and Cultural Context 8: 121-30. [CrossRef]

Rice, Marilyn, and Trevor Hancock. 2016. Equity, sustainability and governance in urban settings. Global Health Promotion $23: 94-97$. [CrossRef]

Rowlands, Jo. 1995. Empowerment examined. Development in Practice 5: 101-7. [CrossRef] [PubMed]

Rowlands, Jo. 2016. Power in practice: Bringing Understandings and Analysis of power into Development Action in Oxfam. Institute of Development Studies. Available online: https:/ /opendocs.ids.ac.uk/opendocs/handle/20.500.12413/12663 (accessed on 4 March 2021).

Sachana, P.C., and A. Anilkumar. 2015. Differential perception of livelihood issues of tribal women: The case of Attappadi the state in Kerala. India. International Journal of Applied and Pure Science and Agriculture 1: 124-28.

Santhosh, Kumar S. 2012. Capacity building through women groups. Journal of Rural Development 31: $235-43$.

Sanyal, P. 2009. From credit to collective action: The role of microfinance in promoting women's social capital and normative influence. American Sociological Review 74: 529-50. [CrossRef]

Saradamoni, K. 1999. Matriliny Transformed. New Delhi: Sage Publications.

Schön, Donald, and Chris Argyris. 1996. Organizational Learning II: Theory, Method and Practice. Reading: Addison Wesley.

Selvi, S.C., and K.S. Pushpa. 2018. Factors influencing on rural women empowerment of Kudumbashree programme. International Journal of Current Advanced Research 7: 9220-23.

Sen, Amartya. 1999. Development as Freedom. Oxford: Oxford University Press.

Siwal, Beg Raj. 2009. Gender Framework Analysis of Empowerment of Women: A Case Study of Kudumbashree Programme. Available online: https: / / ssrn.com/abstract=1334478 (accessed on 15 March 2021).

Tasan-Kok, Tuna, and Jan Vranken. 2008. From survival to competition? The socio-spatial evolution of Turkish immigrant entrepreneurs in Antwerp. Geojournal Library 93: 151.

Thorpe, Jodie, and John Gaventa. 2020. Democratising Economic Power: The Potential for Meaningful Participation in Economic Governance and Decision-Making. IDS. Available online: ids.ac.uk (accessed on 15 March 2021).

UNDP. 2018. Gender Equality Strategy 2018-2021. Available online: https://www.undp.org/content/undp/en/home/librarypage/ womens-empowerment/undp-gender-equality-strategy-2018-2021.html (accessed on 4 March 2021).

UNICEF. 2021. The State of the World's Children. Available online: https://www.unicef.org/reports/state-of-worlds-children (accessed on 4 March 2021).

Vangen, Siv, John Paul Hayes, and Chris Cornforth. 2015. Governing cross-sector, inter-organizational collaborations. Public Management Review 17: 1237-60. [CrossRef]

Varghese, M. 2012. Women Empowerment through Kudumbasree: A Study in Ernakulam District. Available online: https:// shodhgangotri.inflibnet.ac.in/bitstream/123456789/777/1/synopsis.pdf (accessed on 15 March 2021).

Venugopalan, K. 2014. Influence of Kudumbasree on Women Empowerment-a Study. IOSR Journal of Business and Management 16: 35-44. [CrossRef]

Véron, Rene. 2001. The "new" Kerala model: Lessons for sustainable development. World Development 29: 601-17.

Viswanathan, P. K., and Amita Shah. 2016. Gender Impact of Trade Reforms in India: An Analysis of Tea and Rubber Production Sectors. In Globalisation, Development and Plantation Labour in India. Edited by K.J. Joseph and P.K. Viswanathan. London: Routledge, New Delhi: Routledge India (South Asia Edition), pp. 234-65.

Viswanathan, P. K., and Varachai Thongthai. 2009. Gender Differences in Educational Attainments and Occupational Status in Thailand: A study based on Kanchanaburi DSS Data. Journal of Population and Social Studies 17: 83-122.

Warner, Jeroen. 2005. Multi-stakeholder platforms: Integrating society in water resource management? Ambiente E Sociedade 8: 4-28. 
Welter, Frederike, Baker Ted, and Wirsching Katharine. 2019. Three waves and counting: The rising tide of contextualization in entrepreneurship research. Small Business Economics 52: 319-30. [CrossRef]

Williams, Glyn, Binitha V. Thampi, D. Narayana, Sailaja Nandigama, and Dwaipayan Bhattacharyya. 2011. Performing Participatory Citizenship-Politics and Power in Kerala's Kudumbashree Programme. Journal of Development Studies 48: 1261-80. [CrossRef]

Wood, Bronwyn P., Poh Yen Ng, and Bettina Lynda Bastian. 2021. Hegemonic Conceptualizations of Empowerment in Entrepreneurship and Their Suitability for Collective Contexts. Administrative Sciences 11: 28. [CrossRef]

Yin, Robert K. 2014. Case Study Research Design and Methods, 5th ed. Thousand Oaks: Sage. 